\author{
Władysław Góral \\ ORCID 0000-0003-0586-7191
}

\title{
THE SKY DISK OF NEBRA REVEALS ITS SECRETS
}

\author{
AGH University of Science and Technology
}

Keywords: Nebra Sky Disk, Sun, Moon, archeoastronomy

\begin{abstract}
The paper presents the method and results of decoding the content on the Sky Disk of Nebra. It has been shown that the symbols found on it, suggesting the Sun, the Moon and the solar barge are only geometric figures facilitating the recording of astronomical knowledge. The paper first defines a polar system on the horizon plane. This system describes the range of the directions of sunrise and sunset in the annual period and the Moon in the 18.61-year cycle. It turned out that astronomical knowledge was recorded on the surface of the disk on two planes: horizontal and perpendicular one (the meridian plane). With the help of geometric constructions located on the meridian plane, it was possible to decode the range of changes in the altitude (zenith distance) of the Sun in the annual period, at the time of its upper culmination. Also, using two different geometric structures, the range of changes in altitude (zenith distance) of the Moon at the time of its upper culmination in the 18.61-year cycle was decoded.
\end{abstract}

\section{DYSK Z NEBRY ODSŁANIA SWOJE TAJEMNICE}

Słowa kluczowe: Dysk z Nebry, Słońce, Księżyc, archeoastronomia

\begin{abstract}
Abstrakt
W pracy zaprezentowano metodę i wyniki rozkodowania treści zawartej na powierzchni dysku z Nebry. Wykazano, że znajdujące się na nim symbole sugerujące Słońce, Księżyc i barkę słoneczną są tylko figurami geometrycznymi ułatwiającymi zapis wiedzy o charakterze astronomicznym. W pracy wpierw zdefiniowano układ biegunowy na płaszczyźnie horyzontu. W układzie tym opisano zakres kierunków wschodu i zachodu Słońca w okresie rocznym i Księżyca w cyklu 18,61-letnim. Okazało się, że na powierzchni dysku zapisano wiedzę astronomiczną na dwu płaszczyznach: horyzontalnej i na płaszczyźnie do niej prostopadłej (płaszczyźnie południka). Za pomocą konstrukcji geometrycznych znajdujących się na płaszczyźnie południka udało się rozkodować zakres zmian wysokości horyzontalnej (odległości zenitalnej) Słońca w okresie rocznym, w momencie jego kulminacji górnej. Również za pomocą dwu różnych konstrukcji geometrycznych rozkodowano zakres zmian wysokości horyzontalnych (odległości zenitalnych) Księżyca w momencie jego kulminacji górnej w cyklu 18.61-letnim.
\end{abstract}

\section{INTRODUCTION}

The Sky Disk of Nebra was found in 1999 at the archaeological site on the Mittelberg hill, located about $4 \mathrm{~km}$ from the city of Nebra. The sky disk was discovered illegally by treasure hunters using a metal detector. The author [4], Dr. H. Meller, director of the Prehistoric Museum in Halle, Saxony-Anhalt, for the first time de- scribed how the Sky Disk of Nebra was recovered only in 2002. The $32 \mathrm{~cm}$ disk is made of bronze. A number of astronomical signs were marked on its surface with the use of thin gold plates, probably representing the Sun in the form of a circle, a crescent Moon, stars, two symmetrical bows around the circumference of the circle, and a bow in the shape of a solar barge. In addition, there is a grouping of seven stars on the Sky Disk of 


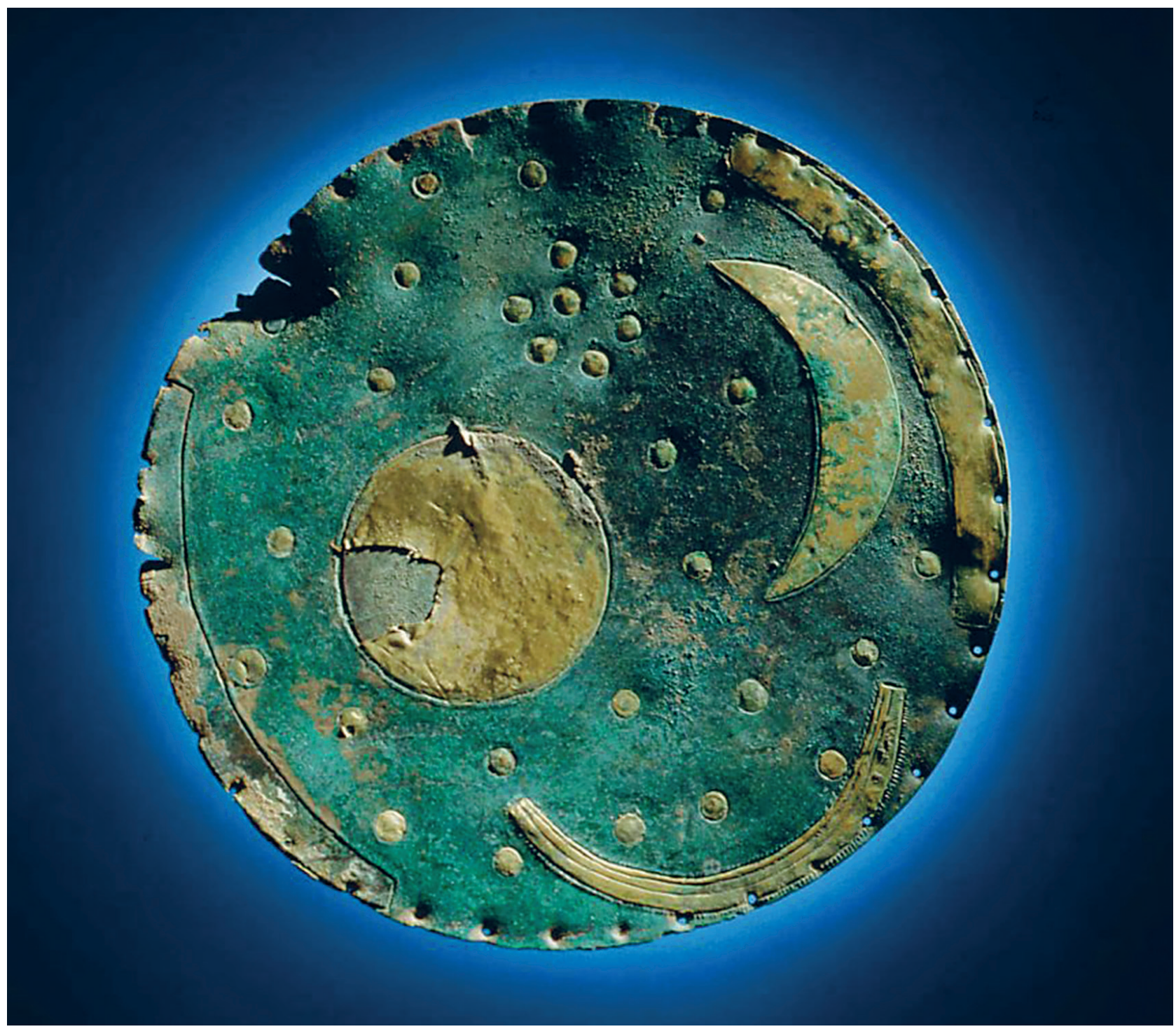

Fig. 1. The Sky Disk of Nebra [5]

Rys. 1. Dysk słoneczny z Nebry [5]

Nebra. This group is associated with the Pleiades, located in the zodiac belt in the constellation of Taurus. Initially, the disk was carefully examined to confirm its authenticity and the age of its construction. The Sky Disk of Nebra was found to be authentic, made in the Bronze Age about 3,600 years ago. The discovery became a great sensation among archaeologists and astronomers. It turned out that the disk was created in several stages. In the initial phase, the symbols of the stars, the Moon and the Sun were marked on the sky disk. A little later, two golden bows were added around its perimeter. The disk became an instrument for tracking the movement of the Sun. Then a golden barge silhouette was added. In the final stage, 39 holes were marked around the entire circumference of the disk, approximately equidistant (Fig. 1).

The Sky Disk of Nebra was entered into the UNESCO Memory of the World Register in 2013 as one of the greatest archaeological discoveries of the $20^{\text {th }}$ century. The astronomical aspects of the discovered sky disk have been extensively described by the astronomer, Prof. Wolfard Schlosser from the University of Ruhr [5]. First, the professor noted two golden bows on either side of the sky disk, documenting the annual 
range of sunrise and sunset azimuths in Central Europe at a latitude of approximately $\varphi=51^{\circ}$. Along this latitude there is the place where the disk was found and the ancient observatory from the Neolithic age in Goseck. The Sky Disk of Nebra continues to inspire astronomers and archaeologists. In articles on astronomy, the authors focus on astronomical phenomena in the past epochs near the Pleiades. However, it is still believed that the disk is a mysterious object difficult to decode. The author's approach presented in this article differs significantly from the publications that have been prepared so far. All objects on the disk found a logical use. Several layers were marked on the horizontal surface of the disk, describing the full range of changes in altitude (zenith distance) of the Sun during the year during the upper culmination on the meridian plane. The changes in altitudes in the Moon's upper culmination over its 18.61-year cycle have been described very thoroughly.

\section{SUNRISES, SUNSETS AND THE MOON ON THE SKY DISK OF NEBRA}

We begin the study of the Sky Disk by introducing a polar horizontal system using two symmetrical gold bows located on its edge. These bands, according to the observation of Prof. Schlosser [5], cover a range of azimuths of $82^{\circ}$ sunrise and sunset times a year. We use the symmetry of the east and west points with respect to the north-south axis. We mark the beginning of the system by means of the extreme directions of sunrise and sunset during the year. We connect the point of sunrise on the day of the summer solstice $-\mathrm{S}_{1}$ with the point of sunset on the day of the winter solstice $-\mathrm{S}_{4}$ (Fig. 2). The second line is created by connecting the point of sunset on the day of the summer solstice, $\mathrm{S}_{2}$ with the point of sunrise on the day of the winter solstice, $S_{3}$. The origin of the $\mathrm{O}$ (Observer) system determines the intersection

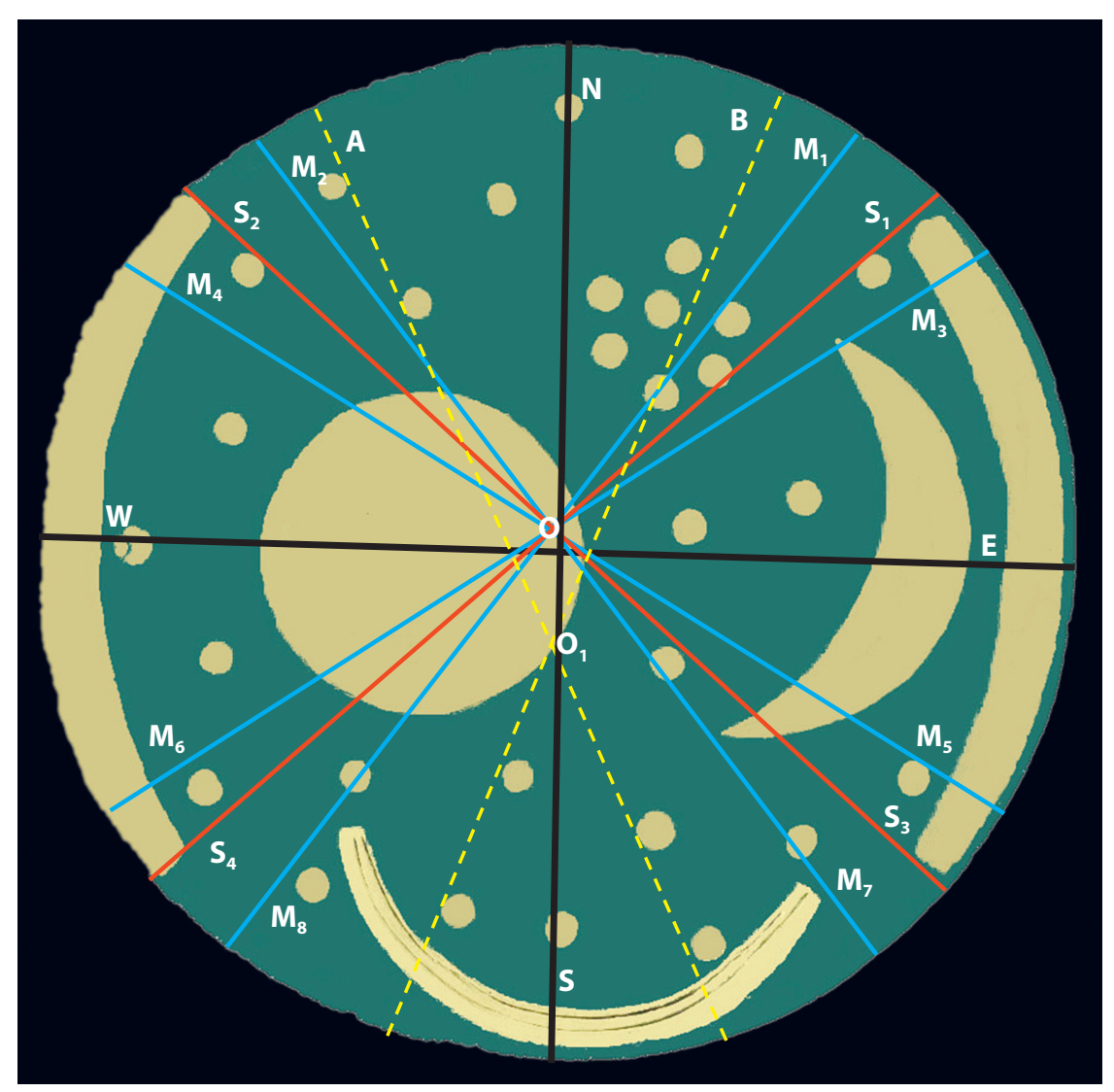

Fig. 2. The range of sunrise and sunset (S) directions during the year and the Moon (M) in the 18.61-year cycle. By W. Góral (background: disk copy, Wikimedia, [6])

Rys. 2. Zakres kierunków wschodu i zachodu Słońca (S) w ciągu roku oraz Księżyca (M) w cyklu 18.61 lat. Oprac. W. Góral (tło: kopia dysku, Wikimedia, [6]) 
point of the two lines. The bisector of the angle $\mathrm{S}_{1} \mathrm{OS}_{2}$ sets the north-south axis. It turns out that this line coincides with the line defined by two points, which we denote as north $-\mathrm{N}$ and south $-\mathrm{S}$. A line perpendicular to the $\mathrm{S}-\mathrm{N}$ axis, drawn through the beginning of the system $\mathrm{O}$, indicates the direction east-west, E-W (Fig. 2). As a result of measuring the angles $\mathrm{S}_{1} \mathrm{OS}_{3}$ and $\mathrm{S}_{4} \mathrm{OS}_{2}$ we get as a result of $82^{\circ}$. Hence, it follows that the azimuths of individual directions are as follows: $\mathrm{OS}_{1}\left(49^{\circ}\right), \mathrm{OS}_{2}$ $\left(311^{\circ}\right), \mathrm{OS}_{3}\left(131^{\circ}\right)$, and $\mathrm{OS}_{4}\left(229^{\circ}\right)$.

On the day of the summer solstice, the declination of the Sun $(\delta)$ reaches its maximum value in a given year, which is equal to the angle of the ecliptic plane to the equatorial plane $(\varepsilon)$. This angle, and therefore the declination of the Sun on the day of the summer solstice, is currently slowly decreasing. At the time of the disk creation, this value was approximately $24^{\circ}$. When calculating the east (west) azimuth of the celestial body, the atmospheric refraction is taken into account. Its standard value on the horizon is $35^{\prime}$. When the centre of the sun's disk is in the horizon plane, the value of the zenith distance is $z=90^{\circ} 35^{\prime}$. When introducing it to the calculations, we use the cosine formula of spherical trigonometry for a parallactic triangle [3].

$$
\cos \mathrm{A}=(\sin \delta-\sin \varphi \cos \mathrm{z}) / \cos \varphi \sin \mathrm{z}
$$

For the zenith distance $\mathrm{z}=90^{\circ}$, this formula is simplified to the following form

$$
\cos \mathrm{A}=\sin \delta / \cos \varphi
$$

Using the above formulas, we check for which latitude range the condition $\mathrm{S}_{3}-\mathrm{S}_{1}=82^{\circ}$ is satisfied.

From the analysis of the data contained in Table 1, we can see that the values of the sunrise azimuths calculated by formula 1 (columns 2-4) differ in the results calculated by formula 2 (columns $5-7$ ) by about one arc degree. In turn, the differences between the azimuth of sunrise on the winter and summer solstices are the same. The condition $\mathrm{S}_{3}-\mathrm{S}_{1}=82^{\circ}$ is best met for a width of more or less $52^{\circ}$. Fig. 2 also introduces 4 directions of the Moon's east: $\mathrm{OM}_{1}, \mathrm{OM}_{3}, \mathrm{OM}_{5} \mathrm{OM}_{7}$ and the directions of its west symmetrical to the $\mathrm{N}-\mathrm{S}$ axis. The moon rises and sets are characterized by two cycles: a monthly cycle and an 18.61-year cycle.

In the monthly cycle, the declination of the Moon varies from $-29^{\circ} 09^{\prime}$ to $29^{\circ} 09^{\prime}$ (High Moon) within one revolution. Then, in the winter full moon at the time of its upper culmination, the Moon rises in the direction of $\mathrm{OM}_{1}\left(38^{\circ} 31^{\prime}\right)$ and culminates at maximum altitude of $67.15^{\circ}$. And during the full moon near the summer solstice, the Moon will be extremely low above the horizon, rising in the direction of $\mathrm{OM}_{7}\left(141^{\circ} 29^{\prime}\right)$ and culminating at $h=8.85^{\circ}$. After 9.3 years, the declination of the Moon varies from $18^{\circ} 09^{\prime}$ to $-18^{\circ} 09^{\prime}$ during one monthly cycle. In this case, at latitude $52^{\circ}$, the azimuth of the direction of the moon rising is in the range: $\mathrm{OM}_{3}\left(58^{\circ} 44^{\prime}\right)$ to $\mathrm{OM}_{5}\left(121^{\circ} 16^{\prime}\right)$.

\section{CULMINATION OF THE SUN AND THE MOON RECORDED ON THE SKY DISK OF NEBRA}

The phenomenon of celestial body culmination, observed in the meridian plane, is described in the horizontal system using the altitude $h$ or the zenith distance $\left(\mathrm{z}=90^{\circ}-\mathrm{h}\right)$. The altitude of a celestial body at the moment of culmination depends on its declination $\delta$, and the latitude $\varphi$ of the observation site and is expressed by the formula: $h=90^{\circ}-\varphi+\delta$. The declination of the Sun during the year, about three thousand years ago, varied in the range from $-24^{\circ}$ to $24^{\circ}$. This knowledge is recorded on the Sky Disk of Nebra by the lines $\mathrm{O}_{1} \mathrm{~A}$ and $\mathrm{O}_{1} \mathrm{~B}$ defined uniquely by three points on the disk (Fig. 2). The angle $\mathrm{AO}_{1} \mathrm{~B}$ is $2 \varepsilon=48^{\circ}$. This is the extent

Table 1. Azimuth values of the directions of sunrises at the solstices

Tabela 1. Azymuty kierunku linii wschodu Słońca w dniu przesilenia letniego i zimowego

\begin{tabular}{|c|c|c|c|c|c|c|}
\hline $\boldsymbol{\varphi}$ & $\mathbf{A}, \boldsymbol{\delta}=\mathbf{2 4}^{\circ}$ & $\mathbf{A}, \boldsymbol{\delta}=-\mathbf{2 4}^{\circ}$ & $\mathbf{S}_{\mathbf{3}}-\mathbf{S}_{\mathbf{1}}$ & $\mathbf{A}, \boldsymbol{\delta}=\mathbf{2 4}^{\circ}$ & $\mathbf{A}, \boldsymbol{\delta}=-\mathbf{2 4}^{\circ}$ & $\mathbf{S}_{\mathbf{3}}-\mathbf{S}_{\mathbf{1}}$ \\
\hline $50^{\circ}$ & $49^{\circ} 50^{\prime}$ & $128^{\circ} 22^{\prime}$ & $78^{\circ} 32^{\prime}$ & $50^{\circ} 45^{\prime}$ & $129^{\circ} 15^{\prime}$ & $78^{\circ} 31^{\prime}$ \\
\hline $51^{\circ}$ & $48^{\circ} 47^{\prime}$ & $129^{\circ} 20^{\prime}$ & $80^{\circ} 33^{\prime}$ & $49^{\circ} 44^{\prime}$ & $130^{\circ} 16^{\prime}$ & $80^{\circ} 32^{\prime}$ \\
\hline $52^{\circ}$ & $47^{\circ} 39^{\prime}$ & $130^{\circ} 22^{\prime}$ & $82^{\circ} 43^{\prime}$ & $48^{\circ} 39^{\prime}$ & $131^{\circ} 21^{\prime}$ & $82^{\circ} 32^{\prime}$ \\
\hline
\end{tabular}




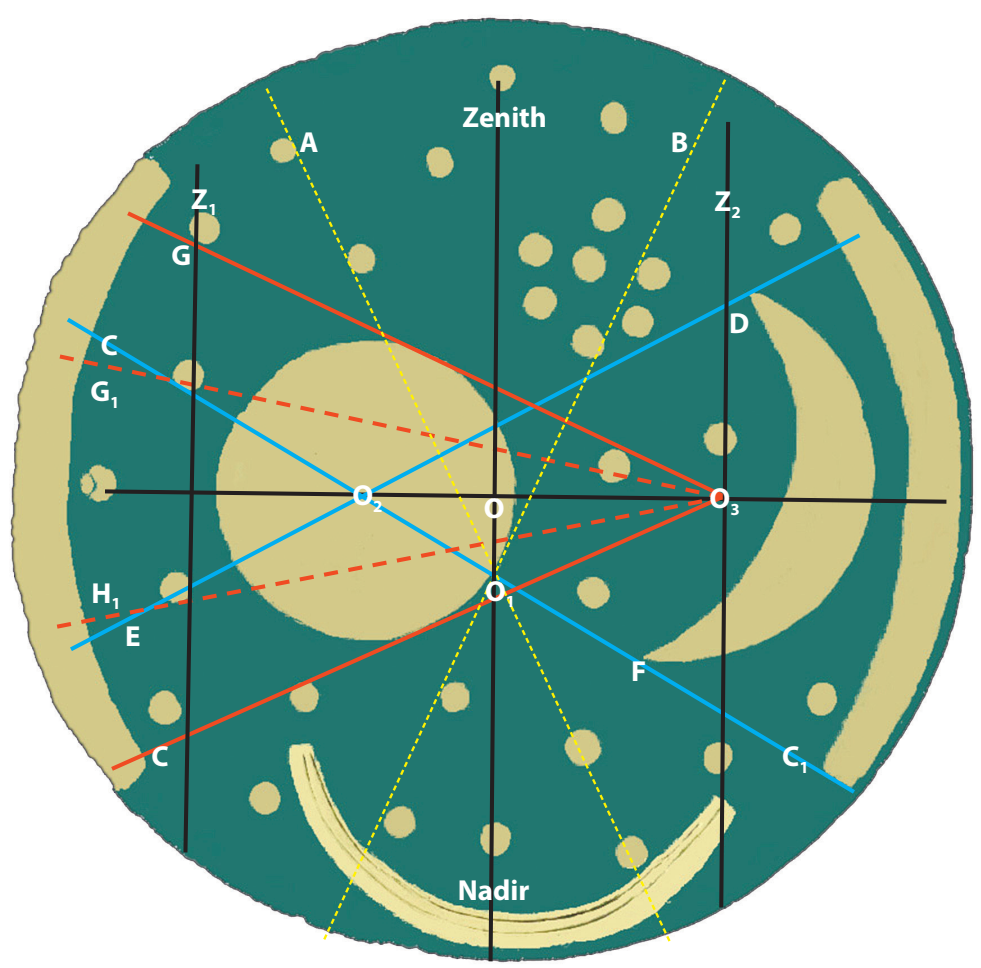

Fig. 3. The range of declination (altitude) of the Sun at the culmination of the year, and the range of the Moon over 18.61 years. By W. Góral (background: disk copy, Wikimedia, [6])

Rys. 3. Zakres deklinacji (wysokości horyzontalnej) Słońca w kulminacji w ciągu roku oraz Księżyca w okresie 18.61 lat. Oprac. W. Góral (tło: kopia dysku, Wikimedia, [6])

to which the declination of the Sun and its altitude change at the peak during the year.

The bisector of this angle $\mathrm{AO}_{1} \mathrm{~B}$ in Fig. 2 coincides with the S-N axis, and in the meridian plane its counterpart is the Zenith-Nadir (Z-N) axis (Fig. 3). The angle marked with the letter $\varepsilon$ determines the deviation of the ecliptic pole from the celestial pole, which is equivalent to the deviation of the ecliptic plane from the celestial equator plane. At the time of the culmination of the upper Sun, on the day of the summer solstice, it is on the plane of the ecliptic, with the maximum deviation north of the equator $\left(24^{\circ}\right)$.

The angle $\mathrm{AO}_{1} \mathrm{~B}$ from Fig. 2 fits perfectly on the disk as the angle $\mathrm{CO}_{3} \mathrm{G}$, which covers the disk of the symbol of the Sun (Fig. 3). The apex of this angle $\mathrm{O}_{3}$ is on the line $Z_{2}$, parallel to the line $Z-N$. The bisector of the angle $\mathrm{CO}_{3} \mathrm{G}$ is perpendicular to the line $\mathrm{Z}-\mathrm{N}$, and passes through the centre of the solar disk along the line $\mathrm{O}-\mathrm{O}_{2}$. The intersection of lines $\mathrm{A}$ and $\mathrm{B}$ marks an additional point $\mathrm{O}_{1}$ on the disk on the $\mathrm{Z}-\mathrm{N}$ axis. It turns out that it lies on the straight line touching the lower Moon symbol $-\mathrm{F}$ and the lower part of the bow $-\mathrm{C}_{1}$. The extension of the line $\mathrm{C}_{1}-\mathrm{F}-\mathrm{O}_{1}$ in the opposite direction marks the point $\mathrm{O}_{2}$ at the intersection with line $\mathrm{O}-\mathrm{O}_{3}$. This point coincides with the centre of the sun's disk. Then we connect point $\mathrm{O}_{2}$ with the upper symbol of the Moon at point $\mathrm{D}$. It turns out that the value of the measured angle $\mathrm{FO}_{2} \mathrm{D}$, including the figure of the Moon, is about $58^{\circ}$. This value is in line with the difference between the Moon's maximum declination value of $29^{\circ}$ and its minimum value of $-29^{\circ}$. The Moon's altitude changes to the same extent over its 18.61-year cycle.

The angle of $\mathrm{CO}_{3} \mathrm{G}$ has been divided by the lines: $\mathrm{O}_{3} \mathrm{G}_{1}, \mathrm{O}_{3} \mathrm{O}_{2}, \mathrm{O}_{3} \mathrm{H}_{1}$ into four approximately equal sectors (Fig. 3). In the direction of $\mathrm{O}_{3} \mathrm{G}_{1}\left(12^{\circ}\right)$, the Sun is at its declination of $12^{\circ}$, which takes place around February 16 and August 20. In the direction of $\mathrm{O}_{3} \mathrm{O}_{2}\left(0^{\circ}\right)$, the Sun is on the Spring and Fall Equinoxes, and similarly in the direction of $\mathrm{O}_{3} \mathrm{H}_{1}\left(-12^{\circ}\right)$, the Sun is around February 16 and October 25. Thus, as it was written on the disk, it 


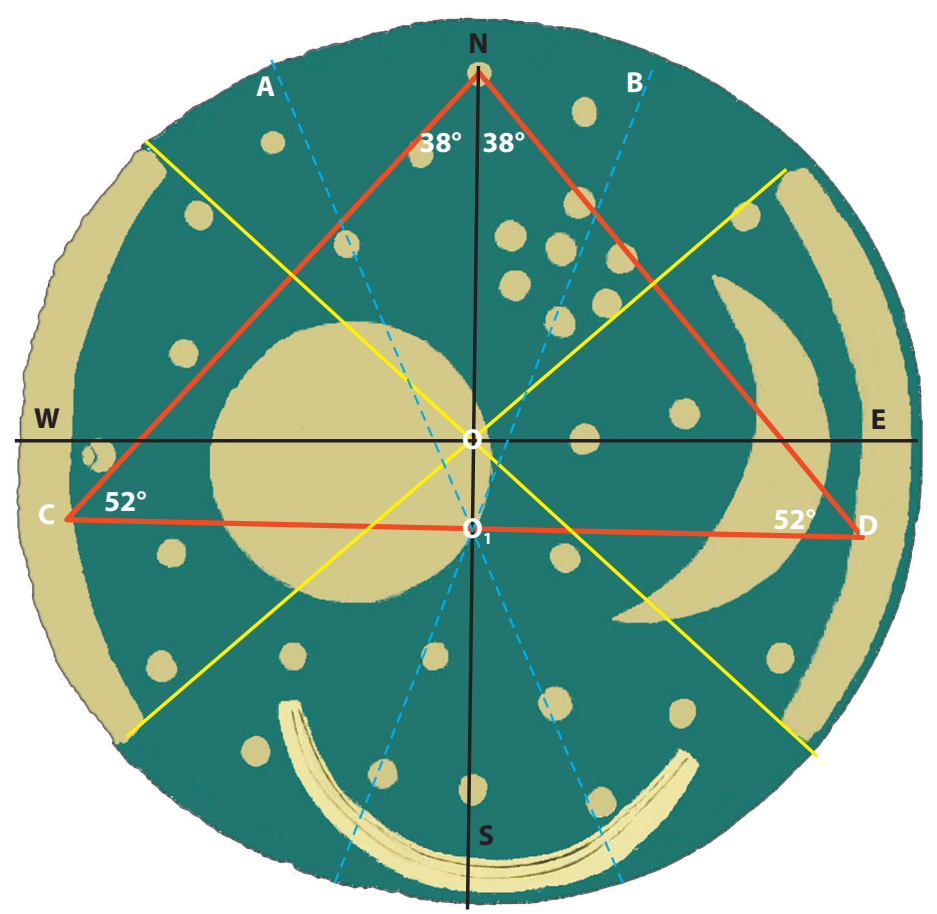

Fig. 4. Angles $52^{\circ}$ and $38^{\circ}$ written in two right triangles $\mathrm{CNO}_{1}$ and $\mathrm{DNO}_{1}$. By W. Góral (background: disk copy, Wikimedia, [6]) Rys. 4. Kąty $52^{\circ}$ i $38^{\circ}$ zapisane w dwu trójkątach prostokątnych $\mathrm{CNO}_{1}$ i $\mathrm{DNO}_{1}$. Oprac. W. Góral (tło: kopia dysku, Wikimedia, [6])

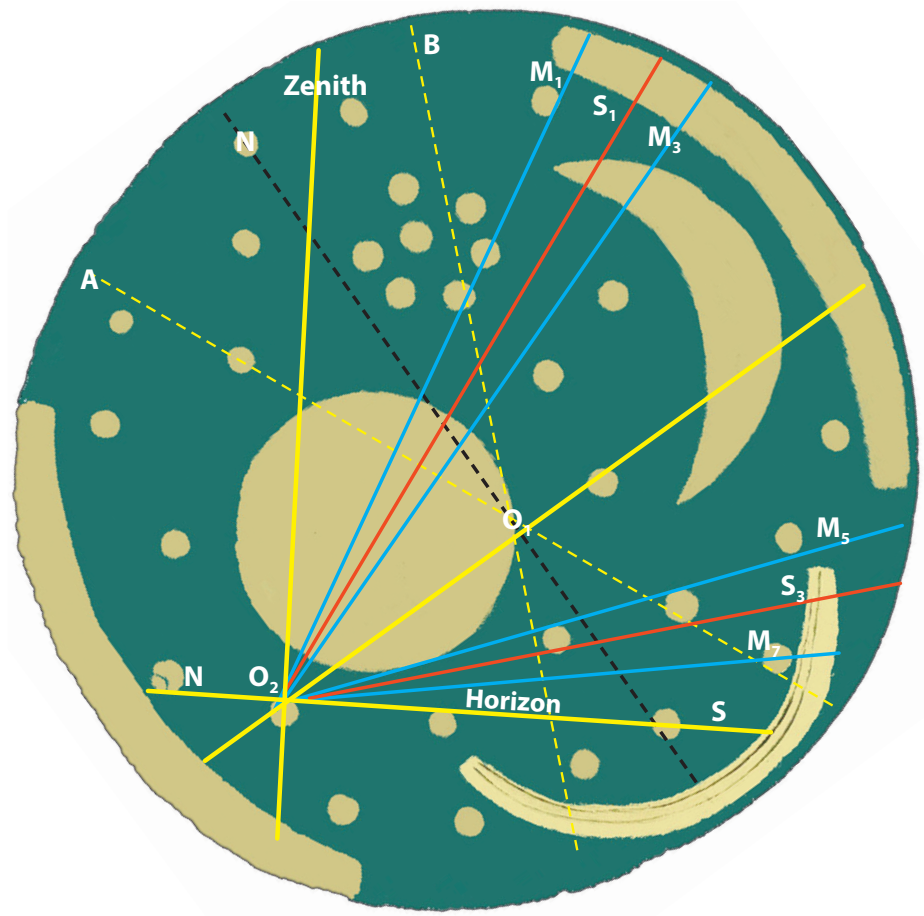

Fig. 5. The altitude (zenith distance) of the Moon and the Sun at its culmination. By W. Góral (background: disk copy, Wikimedia, [6])

Rys. 5. Wysokość horyzontalna (odległość zenitalna) Księżyca oraz Słońca w momencie kulminacji. Oprac. W. Góral (tło: kopia dysku, Wikimedia, [6]) 


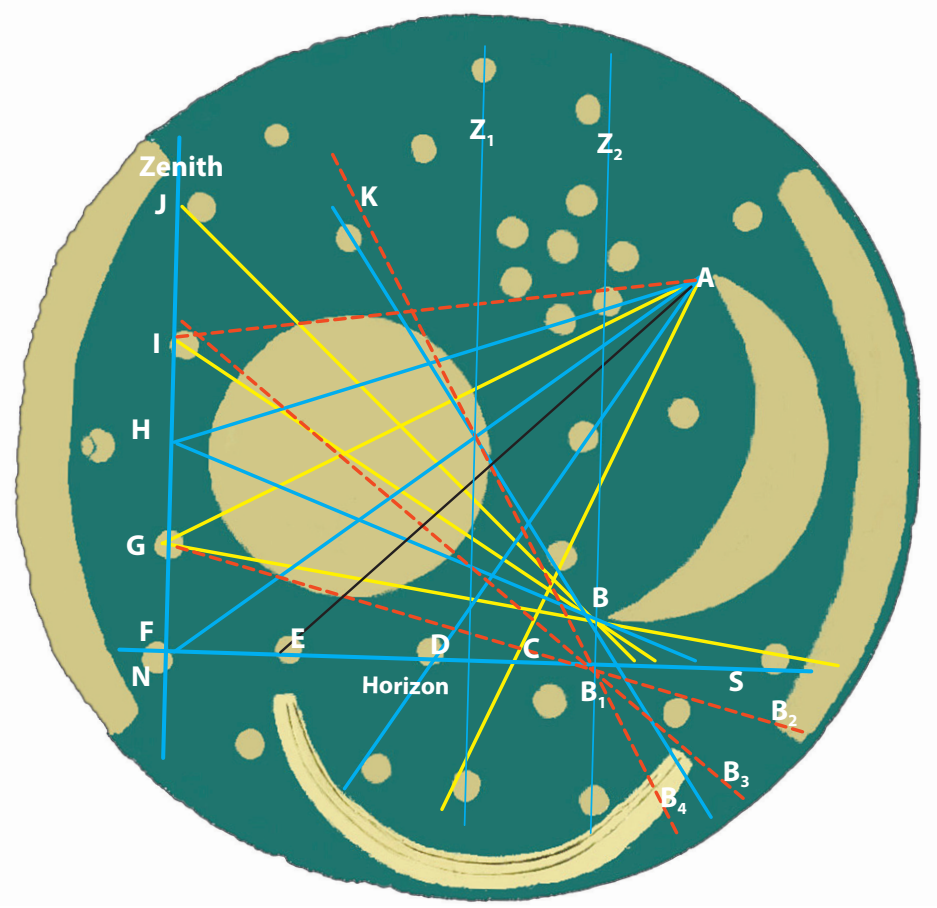

Fig. 6. The altitude of the Moon culminating in the 18.61-year cycle, and of the Sun in the annual period. By W. Góral (background: disk copy, Wikimedia, [6])

Rys. 6. Wysokość horyzontalna Księżyca w kulminacji w cyklu 18.61-letnim, oraz Słońca w okresie rocznym. Oprac. W. Góral (tło: kopia dysku, Wikimedia, [6])

could also be used as a calendar. Particularly noteworthy about the Sky Disk of Nebra are two right-angled triangles: $\mathrm{CNO}_{1}$ and $\mathrm{DCO}_{1}$, symmetrical in relation to the $\mathrm{N}-\mathrm{S}$ axis (Fig. 4). The red-marked CND triangle is an isosceles triangle, which consists of two right triangles. The measured value of the CND angle is $76^{\circ}$, so the other two angles are $52^{\circ}$. The angle of $\mathrm{CNO}_{1}$ of approximately $38^{\circ}$ defines the horizontal height of the celestial equator in the plane of the local meridian. The value of the measured $\mathrm{NCO}_{1}$ angle is related to the parallel of latitude approximately $52^{\circ}$.

On the Sky Disk of Nebra, two methods were successfully deciphered describing the range of changes in the Moon's altitue at its culmination in the 18.61-year cycle, and the Sun's annual cycle. In the first method, presented graphically in Fig. 5, the origin of the system is located at point $\mathrm{O}_{2}$. This drawing enables measurement of the horizontal height from the $\mathrm{O}_{2} \mathrm{~S}$ axis. The angle $\mathrm{SO}_{2} \mathrm{O}_{1}\left(38^{\circ}\right)$ describes the altitude of the celestial equator above the horizon in the plane of the local meridian. The four directions shown in Fig. 5 have been assigned the following altitudes as a function of the
Moon's declination: $\mathrm{O}_{2} \mathrm{M}_{1}\left(67^{\circ}, 29^{\circ}\right), \mathrm{O}_{2} \mathrm{M}_{3}\left(57^{\circ}, 18^{\circ}\right)$, $\mathrm{O}_{2} \mathrm{M}_{5}\left(19^{\circ},-18^{\circ}\right), \mathrm{O}_{2} \mathrm{M}_{7}\left(9^{\circ},-29^{\circ}\right)$.

The range of knowledge describing the moon's culmination in the second method has been increased and graphically significantly improved. Two systems were introduced with the beginning attached at both ends of the Moon symbol: A, B (Fig. 6). The range of changes in the Moon's altitude in the upper culmination in the 18.61-year cycle includes 7 lines hooked at point $\mathrm{A}: \mathrm{A}(\mathrm{IA})=38^{\circ}-\varepsilon-\mathrm{i}=9^{\circ}, \mathrm{A}(\mathrm{HA})=38^{\circ}-\varepsilon+\mathrm{i}=$ $19^{\circ}, \mathrm{A}(\mathrm{GA})=38^{\circ}-2 \mathrm{i}=28^{\circ}, \mathrm{A}(\mathrm{EA})=38+\mathrm{i}=43^{\circ}$, $\mathrm{A}(\mathrm{DA})=38^{\circ}+\varepsilon-\mathrm{i}=57^{\circ}, \mathrm{A}(\mathrm{CA})=38^{\circ}+\varepsilon+\mathrm{i}=67^{\circ}$, $\mathrm{A}(\mathrm{FA})=38^{\circ}$. The lines: $\mathrm{BG}\left(9^{\circ}\right), \mathrm{BH}\left(23^{\circ}\right)$, BI $\left(33^{\circ}\right)$, $\mathrm{BJ}\left(43^{\circ}\right)$, BK $\left(57^{\circ}\right)$ are hooked at point $\mathrm{B}$, at the bottom of the Moon. Three lines marked in red have been hooked at $\mathrm{B}_{1}$, on the horizon line: lines $\mathrm{B}_{2}, \mathrm{~B}_{3}, \mathrm{~B}_{4}$ determine successively the altitude of the Sun at its culmination, at the winter solstice $14^{\circ}$, the spring (autumn) equinox $38^{\circ}$ and at the summer solstice $62^{\circ}$.

Fig. 7 shows the basic geometrical figures on the Sky Disk of Nebra, which were used to determine the values of the desired angular quantities. 


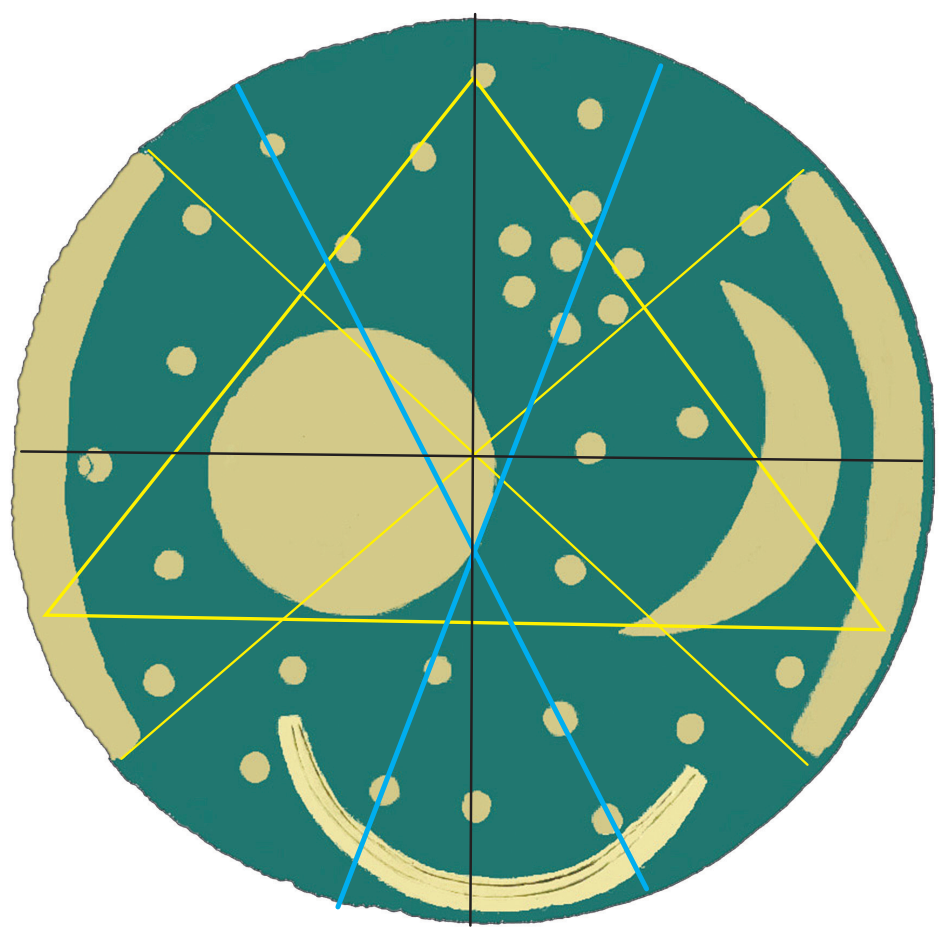

Fig. 7. Basic geometrical figures on the Sky Disk of Nebra. By W. Góral (background: disk copy, Wikimedia, [6]) Rys. 7. Podstawowe figury geometryczne na dysku z Nebry. Oprac. W. Góral (tło: kopia dysku, Wikimedia, [6])

\section{FINAL REMARKS}

A collection of small gold circles plotted on a disk is considered to be symbols of stars in astronomical terms. Many publications have been written on this premise. Despite numerous attempts, it has not been possible to assign them to specific stars or constellations with high probability. In the geodetic aspect, these objects are reference points on the surface of the Earth with which the most important phenomena observed in the sky were recorded and then documented on the disk using the language of geometry. The paper shows that the Sky Disk of Nebra covers a significant range of astronomical knowledge encoded on several layers in the polar horizontal system and on the meridian plane. This knowledge is written using angles in right triangles. The use of the symbols of the Sun, Moon and the sun barge, the shape and location of which fits perfectly with the content of the message, is admirable. In the geodetic aspect, all point features unambiguously define a series of lines with three or more of them. The Sky Disk of Nebra turned out to be a description of an extensive Neolithic observatory. Many astronomical aspects of Stonehenge are mirrored on the surface of the
Sky Disk of Nebra. The author had previously encountered similar problems while studying the astronomical aspects of Krakow's prehistoric mounds [1], [2].

\section{REFERENCES}

[1] Banasik P., Góral W., 2016: Kopiec Krakusa a zachód Słońca w dniu przesilenia letniego, aspekty astronomiczno-archeologiczne, Materiały archeologiczne, Vol. XLI, p. 301-312, http://www.ma.krakow.pl/artykuly.php?i=8.73.156.597 $\underline{\mathrm{gl} l=3 \& \mathrm{j}=0}$.

[2] Góral W., 2018: Krakus and Wanda mounds and the division of a year into eight parts, Geoinformatica Polonica, Vol. 17, p. 109-122, https://www.ejournals.eu/GP/2018/Vol17/art/13146/.

[3] Kreiner J. M., 2009: Ziemia i Wszechświat, Wyd. Naukowe Uniwersytetu Pedagogicznego w Krakowie.

[4] Meller H., 2004, Słoneczny Dysk z Nebry, National Geographic, (Polska), no. 1 (52). p. 45-55.

[5] Schlosser W., Die Himmelsscheibe von Nebra - ein früher Blick des Menschen ins Universum (astronomie.de), https:// www.astronomie.de/astronomische-fachgebiete/archaeoastronomie/himmelsscheibe-von-nebra/ein-frueher-blick-desmenschen-ins-universum/.

[6] Zenz R., 2004: https://commons.wikimedia.org/wiki/File: Nebra-3.jpg\#/media/Plik:Nebra-3.jpg. 